\title{
Ocular motor apraxia, Cogan type
}

INSERM

\section{Source}

INSERM. (1999). Orphanet: an online rare disease and orphan drug data base. Ocular motor apraxia, Cogan type. ORPHA:1125

Ocular motor apraxia, Cogan type is characterised by impairment of voluntary horizontal eye movements and compensatory head thrust. Around 50 cases have been described so far. The oculomotor manifestations tend to improve with age but the syndrome may also be associated with learning and speech difficulties, or, in some cases, cerebral malformations. Both sporadic and familial forms have been described, with sporadic forms being more frequent. The mode of transmission of the familial form has not yet been clearly established. A gene located on the long arm of chromosome 2, near to the NPHP1 gene involved in nephronophthisis, may be associated with ocular motor apraxia, Cogan type. 